\title{
Unraveling the Role of Respiratory Muscle Metaboloreceptors under Inspiratory Training in Patients with Heart Failure
}

\author{
Hugo Fernández-Rubio ${ }^{1}$, Ricardo Becerro-de-Bengoa-Vallejo ${ }^{1}$, David Rodríguez-Sanz ${ }^{1}$, César Calvo-Lobo ${ }^{1, * \mathbb{D}}$, \\ Davinia Vicente-Campos ${ }^{2}\left[\right.$ and Jose López Chicharro ${ }^{1,3}$ \\ 1 Faculty of Nursing, Physical therapy and Podiatry, Universidad Complutense de Madrid, \\ 28040 Madrid, Spain; hugofern@ucm.es (H.F.-R.); ribebeva@enf.ucm.es (R.B.-d.-B.-V.); \\ davidrodriguezsanz@ucm.es (D.R.-S.); jlopezch@ucm.es (J.L.C.) \\ 2 Faculty of Health Sciences, Universidad Francisco de Vitoria, Pozuelo de Alarcón \\ 28223 Madrid, Spain; davinia.vicente@ufv.es \\ 3 Grupo FEBIO, Universidad Complutense de Madrid, 28040 Madrid, Spain \\ * Correspondence: cescalvo@ucm.es
}

Citation: Fernández-Rubio, $\mathrm{H}$.; Becerro-de-Bengoa-Vallejo, R.; Rodríguez-Sanz, D.; Calvo-Lobo, C.; Vicente-Campos, D.; Chicharro, J.L. Unraveling the Role of Respiratory Muscle Metaboloreceptors under Inspiratory Training in Patients with Heart Failure. Int. J. Environ. Res. Public Health 2021, 18, 1697. https://doi.org/10.3390/ ijerph18041697

Academic Editors: Anna Prats-Puig and Sergi Garcia-Retortillo

Received: 29 December 2020

Accepted: 6 February 2021

Published: 10 February 2021

Publisher's Note: MDPI stays neutral with regard to jurisdictional claims in published maps and institutional affiliations.

Copyright: (c) 2021 by the authors. Licensee MDPI, Basel, Switzerland. This article is an open access article distributed under the terms and conditions of the Creative Commons Attribution (CC BY) license (https:// creativecommons.org/licenses/by/ $4.0 /)$.

\begin{abstract}
Exercise intolerance may be considered a hallmark in patients who suffer from heart failure (HF) syndrome. Currently, there is enough scientific evidence regarding functional and structural deterioration of skeletal musculature in these patients. It is worth noting that muscle weakness appears first in the respiratory muscles and then in the musculature of the limbs, which may be considered one of the main causes of exercise intolerance. Functional deterioration and associated atrophy of these respiratory muscles are related to an increased muscle metaboreflex leading to sympathetic-adrenal system hyperactivity and increased pulmonary ventilation. This issue contributes to increased dyspnea and/or fatigue and decreased aerobic function. Consequently, respiratory muscle weakness produces exercise limitations in these patients. In the present review, the key role that respiratory muscle metaboloreceptors play in exercise intolerance is accurately addressed in patients who suffer from HF. In conclusion, currently available scientific evidence seems to affirm that excessive metaboreflex activity of respiratory musculature under HF is the main cause of exercise intolerance and sympathetic-adrenal system hyperactivity. Inspiratory muscle training seems to be a useful personalized medicine intervention to reduce respiratory muscle metaboreflex in order to increase patients' exercise tolerance under HF condition.
\end{abstract}

Keywords: exercise; heart failure; personalized medicine; pulmonary ventilation; respiratory muscles

\section{Introduction}

Heart failure (HF) has a high prevalence, affecting up to 23 million persons worldwide [1]. This condition generates a high impact on functional activity, quality of life and the aging process. In addition, it is a great economic burden for the healthcare system. HF is presented as a multifactorial condition that affects neuro-humoral, structural, molecular and cellular mechanisms, involving all these systems simultaneously in a network that impairs physiological function. All complex and coordinated activities may generate ventricle overload and greater sympathetic-adrenal activity, which may be associated with excessive peripheral vasoconstriction leading to blood flow limitation of locomotor system muscles. This circulation redistribution results in a complex clinical syndrome [2,3], which produces an impaired filling of ventricles with or without a reduced fraction of ejection [4], associated with a progressive deterioration of the musculoskeletal function [5-7]. Indeed, the pumping HF to meet the metabolic tissue demands, together with the peripheral functional impairment, may lead to dyspnea, exercise intolerance, fatigue and peripheral or lung edema $[1,4,5]$. HF patients suffer from a great rate of mortality and morbidity, common hospitalizations and poor quality of life [8]. This syndrome may be categorized into HF including reduced fraction of ejection (HFrEF) and HF including preserved fraction of 
ejection (HFpEF). Subjects with ejection fractions $\geq 50 \%$ are diagnosed as patients with HFpEF, while patients who present an ejection fraction from $41 \%$ to $49 \%$ are diagnosed as patients with HFrEF [1]. In addition, the New York Heart Association (NYHA) created a categorization for HF classes: class I, without symptoms or limitations; class II, slight symptoms or limitations for physical activity; class III, important symptoms or limitations for physical activity; and class IV, symptoms or limitations at resting state [9].

Exercise intolerance plays a primary role in HF patients linked to nonfavorable prognosis [10]. HF patients suffer from an altered respiratory pattern as well as dyspnea with physical activity $[10,11]$. In spite of the common HF sequelae, there is a lack of a clear association between exercise intolerance and cardiac functioning parameters, such as ejection fraction, volume of the left ventricle and cardiac output [10]. Hemodynamic alterations are considered key factors that produce HF symptoms secondary to heart ineffectiveness, generating an increase in cardiac output and venous pressures of systemic and pulmonary mechanisms. New evidence supports a muscular hypothesis suggesting skeletal muscle deterioration as the main cause of HF symptoms [6,11-13]. Muscular weakness present in HF patients occurs more commonly in inspiratory muscles than in the lower limb muscles $[11,14,15]$. The atrophy of these skeletal muscles is produced due to decreased cardiac output as well as tissue hypoxia processes, inflammation alterations, higher systemic catabolism and longer immobilization periods [7]. These alterations are linked to protein degradation, a higher presence of myokines and muscle fiber changes from slowtwitch or type I fibers to fast-twitch or type II fibers [5,16]. Indeed, impaired oxidative metabolism and early acidosis are produced due to a lower presence of mitochondria, decreased density of the mitochondrial ridges and reduced mitochondrial enzymatic activity decreasing enzymes such as 3-hydroxyacyl-CoA dehydrogenase, succinate dehydrogenase and citrate synthetase [16]. Consequently, these processes lead to muscular resistance reduction, afferent reflexes or meta-reflex activation, as well as sustained and increased sympathetic-adrenal activity $[17,18]$. Furthermore, ventilation pattern alterations produce greater dyspnea, higher fatigue and reduced aerobic capacity [5-7,16-18]. Therefore, inspiratory muscle weakness has been associated with HF leading to potential adverse effects $[11,13]$. Inspiratory muscle weakness is linked to greater muscle meta-reflex, playing a key role in HF prognosis [19].

Muscular meta-reflex is a blood flow regulator mechanism for cardiac output, blood pressure and regional distribution, and it involves chemical receptors of muscle parenchyma activated by metabolites secondary to muscle contractile properties [20,21]. Afferent fibers of muscle tissue involved in the meta-reflex consist of nonmyelinated group IV neurons, including chemical sensitive receptors for metabolites secondary to skeletal muscle contraction $[5,20-22]$. Currently, there is a lack of scientific evidence to determine the specific kind of metabolite that activates the muscle meta-reflex [23]. Nevertheless, potassium, lactic acid, adenosine, diprotonated phosphate, arachidonic acid, prostaglandins, capsaicin and serotonin have been suggested as possible specific metabolites that activate the muscle metaboreflex, but not for adenosine and acidic $\mathrm{pH}[20,22,24,25]$. These metabolic stimuli induced by muscle contraction activate molecular receptors located at the terminal end of unmyelinated nerve fibers, such as group IV fibers which are mainly metabolosensitive. Consequently, a spontaneous discharge of the muscle afferent fibers is projected through the input dorsal root of the spinal cord and spreads to the dorsal horns of various spinal cord segments. Muscle fiber inputs reach various integration levels. These reflexes do not seem to need activity of the rostral brain, although supraspinal integration could coexist. In addition, the medulla is considered the control area for cardiovascular responses under activation of the mechanometaboreflexes [5,26]. Efferent responses to the activation of muscular meta-reflexes may comprise higher activity of sympathetic nerves constricting systemic vessels, as well as increasing blood flow in contracted muscular fibers and provoking cardiac ionotropic responses and chronotropic effects to produce greater output at the same time. Thus, muscle metareflex generates sympathetic-adrenal responses, which increase blood pressure for exercise performance, allowing blood flow and volume redistribution [20]. 
According to the detailed process, respiratory muscle meta-reflex appears secondary to fatigue during activity that produces metabolic subproduct accumulation, triggering the activation of the receptors in unmyelinated type IV phrenic afferent fibers; projecting towards the centers of supraspinal brainstem regions implicated in the control of somatosensory cortex, hypothalamus, cerebellum and cardiorespiratory centers; and consequently provoking the meta-reflex activation of these muscles [20-22,27-31]. In addition, these meta-reflexes activate a sympathetic response, leading to vasoconstriction at a peripheral level, blood flow reduction of skeletal muscular perfusion, fatigue increase induced by exercise and redistribution of blood flow of respiratory muscles to maintain adequate functioning. Current scientific evidence suggests that one of the main reasons why the diaphragm suffers less vasoconstriction than the limb muscles is due to the fact that the diaphragm presents fewer $\alpha 1$-adrenergic receptors, but more evidence is required to affirm this statement $[20,27,29,31-34]$. The increased fatigue of skeletal muscle leads to intolerance under exercise activity and reduced strength of the muscular system $[27,29]$. Furthermore, respiratory muscle meta-reflex produces increased heart rates and blood pressure and reduced blood flow in renal, mesenteric and limb arterial vessels, leading to reduced $\mathrm{O}_{2}$ diffusion to muscles $[22,25,28]$.

Regarding patients who suffer from HF, muscle metaboreflex presents an exaggerated activity due to key changes in skeletal muscle, leading to excessive afferent feedback to group IV receptors. One of the main causes of such exaggerated activation is the histological alteration of skeletal muscle fibers that indicates a change in the proportion of fiber type and the expression of the chain isoform of heavy myosin. These myosin chains of type I and gain of type IIx may provoke an increase in metabolic activity, a reduction of oxidative capacity and an increase in group IV afferent activation. Thus, this leads to an increase in vascular resistance at a systemic level, limiting cardiac output, stroke volume and $\mathrm{O}_{2}$ supply and generating impaired exercise capacity and peak $\mathrm{VO}_{2}$ in HF patients [35-38].

Inspiratory muscle weakness appears in approximately $50 \%$ of HF patients [30], contributing to a worse prognosis for these patients [32]. The diagnosis of HF is performed when the maximum inspiratory pressure $\left(\mathrm{PI}_{\max }\right)$ fraction is $<70 \%$ with respect to the normalized value based on a patient's age and gender $[11,39]$ or when $\mathrm{PI}_{\max }$ direct values are $\leq 60 \mathrm{cmH}_{2} \mathrm{O}$ [40]. PI $\mathrm{I}_{\max }$ seems to be linked to the perception of dyspnea for daily activity, being considered as a prognostic indicator for HF patients [30,33,41,42]. Dyspnea and fatigue symptoms presented in HF patients may be partially due to respiratory muscle weakness $[11,29,30,43-46]$ associated with decreased respiratory muscle strength, which leads to a higher $\mathrm{PI}_{\max }$ fraction for the respiration process. Thus, patients note a higher intensity of dyspnea secondary to increased $\mathrm{PI}_{\max }$ fractions for this process [47]. In addition, respiratory musculature weakness is linked to reduced tidal volume, which produces a higher ratio of ventilation-dead space and increased ventilation-perfusion mismatch for exercise activities performed by HF patients. Furthermore, increased correlations between $\mathrm{CO}_{2}$ and ventilation are presented as the main prognostic indicators for these individuals [29,45-47]. In conclusion, inspiratory muscle weakness increases fatigue, promoting early metaboloreceptor activation in respiratory muscles [32].

In addition, weakness of respiratory muscles may be associated with histological alterations. Respiratory muscle biopsies carried out in HF patients showed a reduced percentage in both type IIx muscle fibers and type IIa muscle fibers, as well as a greater proportion of type I muscle fibers with respect to healthy controls [7,48-50]. These alterations seem to differ from those presented in the skeletal musculature of limbs [7]. Although the type I muscle fiber proportions seem to commonly increase in respiratory musculature, respiratory muscle atrophy is presented in HF patients $[29,39,50]$. In addition, a greater proportion of type I muscle fiber is linked to higher oxidative activity of enzymes under HF conditions. All those alterations could be secondary to myogenic factors of regulation associated with an increased effort for sustained ventilation. This adaptation process may facilitate an increase in respiratory resistance, accompanied by a parallel reduction of muscular power and maximum strength for these muscles [30,48]. 
Considering other factors that modify respiratory functions in conjunction with inspiratory muscle weakness under HF condition, increased respiratory activity may be presented secondary to respiratory musculature because it must function against higher elastic and/or resistive loads [10]. Increased elastic load appears to be a consequence of higher stiffness of the pulmonary tissue secondary to the intrathoracic space competition between heart tissue and the lungs, such as the presence of congested pulmonary flow, cardiomegaly, bronchial vascular flows and pulmonary interstitial edema. An increase in resistive loads may lead to congestion of the lungs associated with limited expiratory flows as well as sustained hyperventilation [10,11,29], resulting in higher blood flow and oxygen requirements for respiratory muscles. HF seems to be accompanied by a limited response in cardiac output under exercise activity, and thus the fatigue appears earlier [10]. In addition, Yamada et al. [29] reported that HF patients who present respiratory muscle weakness are likely to show functional capacity limitations in 6-min walking tests, regardless of muscle weakness in the lower extremities or restrictive patterns of the respiratory system. In addition, weakness of inspiratory musculature is linked to various NYHA functional classes, with the greatest inspiratory forces found in individuals who suffer from class I HF and the lowest inspiratory forces found in class IV HF patients $[30,51]$.

Indeed, inspiratory muscle weakness together with increased breathing load may facilitate the fatigue process of these muscles, producing early activation of metaboloreceptors of the respiratory musculature. This process causes exaggerated metaboreflex activity in the respiratory muscles of HF patients. It should be noted that this increased activity may also produce higher hyperventilation in these patients, since the afferents of group IV neurons through dorsal horns of spinal cord neural structures reach respiratory centers of the medulla, such as the rostral ventral cord, caudal ventro-lateral cord and solitary tractus nucleus, generating an exacerbated fatigue of the respiratory muscles [10,32]. Furthermore, muscle metaboreflex, in conjunction with weakness of these muscles, may be considered an important activator of chemoreflex, through peripheral and/or central stimuli, under HF condition. This provokes activation under a lower threshold, which leads to sustained increases in sympathetic activity and causes adrenergic vasoconstrictions, as well as an increase in right and/or left ventricular afterload. Thus, sympathetic hyperactivation is considered an important mortality predictor in HF patients [32].

An interesting method used to investigate respiratory muscle fatigue and its consequent activation of the metaboreflex in HF patients with exercise intolerance is the use of a noninvasive mechanical ventilator to reduce the inspiratory muscle load [52-55]. In these studies, the load reduction of these muscles increased blood flow of limbs, cardiac output, muscle oxygen absorption $\left(\mathrm{VO}_{2}\right)$, muscle oxygen diffusing capacity $\left(\mathrm{DMO}_{2}\right)$ and exercise tolerance and decreased the vascular resistance of limbs and sympathetic-adrenal system activity. Respiratory muscle metaboreflex needs the limbs' blood flow since the discharge of the inspiratory muscles produces increased blood flow in the extremities and a reduction of blood flow in the respiratory musculature [52-55]. Therefore, it seems that inspiratory musculature training (IMT) could be presented as a useful therapy in order to decrease the respiratory muscle metaboreflex, which could reduce fatigue of these muscles [56].

\section{Material and Methods}

\subsection{Study Design}

A study design of narrative review was used according to "Preferred Reporting Items of Systematic Review \& Meta-analyses (PRISMA)" guidelines [57]. The present study was carried out in order to provide an update of available information of previous systematic reviews considering the reduction of respiratory muscle metaboreflex by IMT in HF patients $[42,58]$, including various study types such as quasi-experimental studies and clinical trials with publication dates before September 2020. 


\subsection{Search Strategies}

A database search was performed in September 2020. PubMed was the database used for this search process. Used restrictions were experimental records providing full access by the search strategy named as ("inspiratory muscle training" OR "respiratory muscle training") AND "heart failure" included in abstract and/or title of English and/or Spanish language studies [56].

\subsection{Study Selection}

Inclusion selection criteria consisted of experimental records of different types, such as clinical trials and/or quasi-experimental studies analyzing the effects of IMT on respiratory muscle metaboreflex in HF patients. Exclusion criteria included nonexperimental research studies and meta-analyses or systematic reviews that comprised patients with comorbidities in conjunction with IMT such as stroke, lung hypertension, Fontan circulation and mitral valve pathologies, among other conditions, as well as all studies that did not analyze IMT effects on respiratory muscle metaboreflex. All possible outcome measurements analyzing IMT effects in an isolated way or in conjunction with other treatments on metaboreflex of respiratory muscles were included in this review in order to update the available information on HF patients [42,58].

\subsection{Data Extraction Processes}

Research features including sample sizes, demographic and social data, baseline outcome measures, training protocols, detailed schedule, frequencies, intensities, IMT devices and protocols were recorded and are detailed in Tables 1 and 2.

Data extraction included study citations, intervention groups, sample size, mean \pm standard deviation (SD), $p$-value to detail statistical significance and supplemental information on measurement procedures; these results are detailed in Tables 1 and 2 following the updated review studies $[42,58]$.

\section{Results and Discussion}

\subsection{Flow Chart}

From 105 studies that were identified by search processes, 100 records were removed according to exclusions and duplicates. Lastly, five records were selected for the narrative synthesis, as shown in Figure 1.

\subsection{IMT Effects on Metaboreflex in HF Patients}

IMT is a training intervention using workloads for inspiration [42]. IMT may be carried out utilizing three different devices such as inspiratory threshold, resistive load and isocapnic hyperpnea devices. Firstly, IMT by inspiratory threshold device uses inspiratory pressures to provoke the openness of a valve allowing air flows to pass for the inspiratory process. Secondly, IMT by resistive load device uses several holes of different reduced diameters which generate resistance for the inspiratory process. Thirdly, IMT by isocapnic hyperpnea device uses an equipped laboratory of respiratory physiology to maintain a ventilation level for volitional hyperpnea for $12 \mathrm{~min}$ while the $\mathrm{CO}_{2}$ is combined with the inspiration air maintaining isocapnia status for the arterial blood flows [59].

Inspiratory muscle weakness presented in HF patients may be reversible. Therefore, IMT is a useful intervention for improving the strength and/or resistance of inspiratory musculature in HF patients [56,60].

Currently, a total of 30 papers have studied the IMT effects in HF patients [28,39,40,44,61-86]. From these 30 studies, only 5 studies $[28,66,67,74,85]$ analyzed the IMT effects on respiratory muscle metaboreflex. Four studies were randomized clinical trials $[28,66,74,85]$ and one study was a quasi-experimental study [67] (Table 1). Sample sizes were small for most of these studies. All studies were performed in HFrEF patients $[28,66,67,74,85]$. IMT modality applied in two studies was inspiratory training with threshold devices [67,74], and two studies applied resistive 
load devices [66,85]. Concretely, Moreno et al.'s [28] study provided the IMT intervention group with the possibility to apply devices for resistive load or threshold (Table 2).
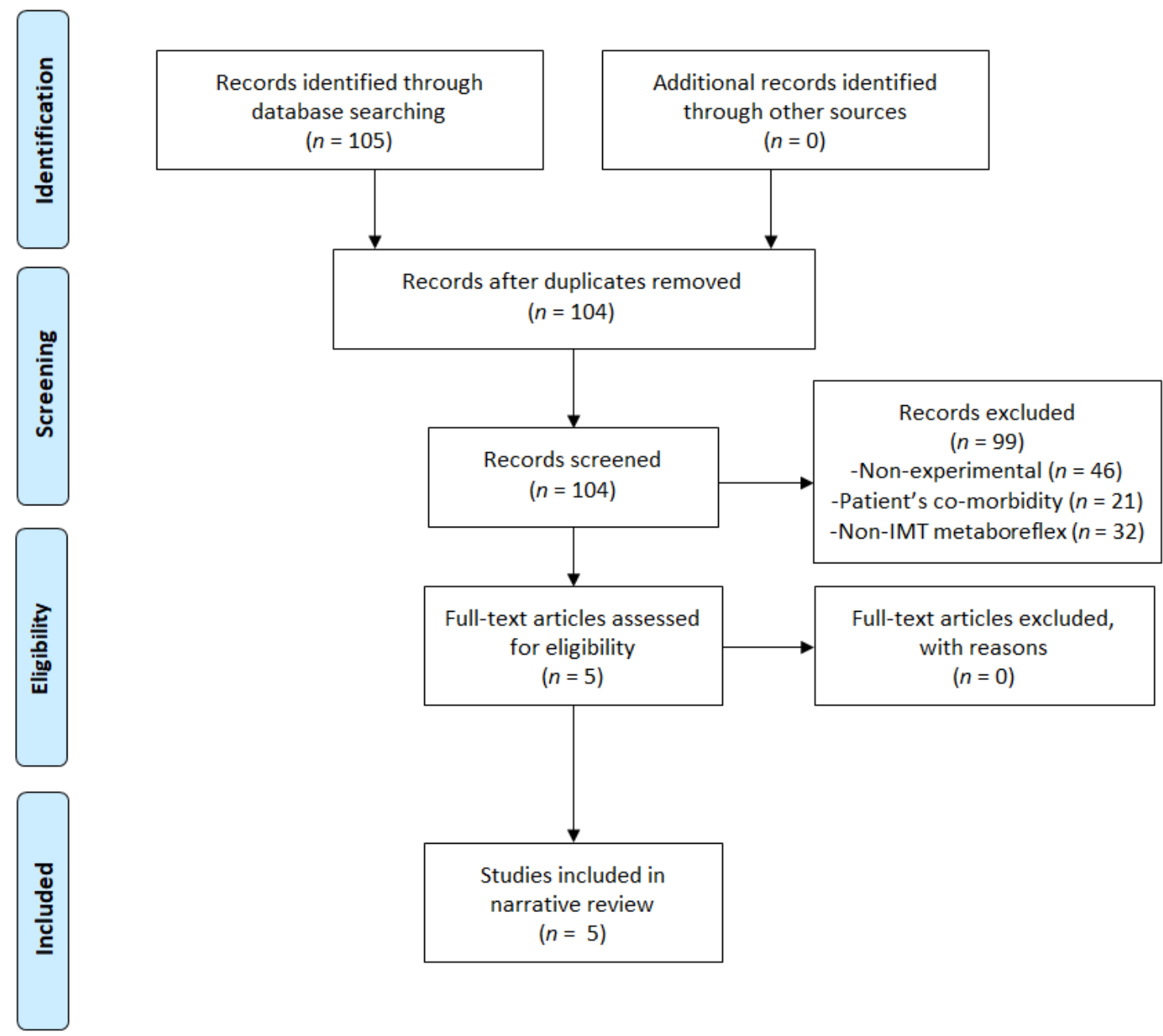

Figure 1. Flow chart.

Table 1. Characteristics of the studies.

\begin{tabular}{|c|c|c|c|c|c|}
\hline Year and Author & $\begin{array}{c}\text { Group }(n), \\
\text { Male/Female }\end{array}$ & Age (Years) & $\begin{array}{l}\text { NYHA Class } \\
\text { (II/III) }\end{array}$ & LVEF (\%) & $\mathrm{PI}_{\max }\left(\mathrm{cmH}_{2} \mathrm{O}\right)$ \\
\hline $\begin{array}{l}\text { 2008. Chiappa } \\
\text { et al. [67] * }\end{array}$ & $\begin{array}{c}\text { IMT: } 18,12 / 6 \\
\text { C: } 10,8 / 2 \\
\text { (Healthy subjects) }\end{array}$ & $\begin{array}{l}\text { IMT: } 57 \pm 11 \\
\text { C: } 38 \pm 12\end{array}$ & $\begin{array}{l}\text { IMT: } 10 / 8 \\
\text { C: N/A }\end{array}$ & $\begin{array}{c}\text { IMT: } 24 \pm 3 \\
\text { C: N/A }\end{array}$ & $\begin{array}{l}\text { IMT: } 60 \pm 8 \\
\text { C: } 153 \pm 26\end{array}$ \\
\hline $\begin{array}{l}\text { 2008. Laoutaris } \\
\text { et al. [66] }\end{array}$ & $\begin{array}{l}\text { IMT: } 14,11 / 3 \\
\text { C: } 9,9 / 0\end{array}$ & $\begin{array}{c}\text { IMT: } 53.4 \pm 2.1 \\
\text { C: } 57.3 \pm 4\end{array}$ & $\begin{array}{l}\text { IMT: } 9 / 5 \\
\text { C: } 6 / 3\end{array}$ & $\begin{array}{c}\text { IMT: } 28.9 \pm 2.4 \\
\text { C: } 28.6 \pm 1.9\end{array}$ & $\begin{array}{c}\text { IMT: } 78.5 \pm 4.9 \\
\text { C: } 84.6 \pm 5.9\end{array}$ \\
\hline $\begin{array}{l}2012 . \\
\text { Mello et al. [74] }\end{array}$ & $\begin{array}{l}\text { IMT: } 15,9 / 6 \\
\text { C: } 12,5 / 7\end{array}$ & $\begin{array}{l}\text { IMT: } 54.3 \pm 2 \\
\text { C: } 53.3 \pm 2\end{array}$ & $\begin{array}{l}\text { IMT: } 15 / 0 \\
\text { C: } 12 / 0\end{array}$ & $\begin{array}{c}\text { IMT: } 33.6 \pm 2.3 \\
\text { C: } 37.6 \pm 1.6\end{array}$ & $\begin{array}{c}\text { IMT: } 56.1 \pm 2.3 \\
\text { C: } 56.2 \pm 2.1\end{array}$ \\
\hline $\begin{array}{l}\text { 2017. Moreno } \\
\text { et al. [28] }\end{array}$ & $\begin{array}{c}\text { IMT: } 13,8 / 5 \\
\text { C:13, } 8 / 5\end{array}$ & $\begin{array}{l}\text { IMT: } 61 \pm 14 \\
\text { C: } 60 \pm 13\end{array}$ & $\begin{array}{l}\text { IMT: } 6 / 7 \\
\text { C: } 7 / 6\end{array}$ & $\begin{array}{c}\text { IMT: } 35 \pm 9 \\
\text { C: } 37 \pm 6\end{array}$ & $\begin{array}{l}\text { IMT: } 60 \pm 13 \\
\text { C: } 60 \pm 16\end{array}$ \\
\hline $\begin{array}{l}\text { 2020. Antunes } \\
\text { Correa et al. [85] }\end{array}$ & $\begin{array}{c}\text { IMT: } 11,3 / 8 \\
\text { C: } 10,6 / 4 \\
\text { AET: } 12,7 / 5\end{array}$ & $\begin{array}{c}\text { IMT: } 55 \pm 3 \\
\text { C: } 57 \pm 3 \\
\text { AET: } 57 \pm 2\end{array}$ & $\begin{array}{c}\text { IMT: } 8 / 3 \\
\text { C: } 9 / 1 \\
\text { AET: } 9 / 3\end{array}$ & $\begin{array}{c}\text { IMT: } 31 \pm 2 \\
\text { C: } 25 \pm 1 \\
\text { AET: } 26 \pm 2\end{array}$ & $\begin{array}{c}\text { IMT: } 86 \pm 9 \\
\text { C: } 85 \pm 8 \\
\text { AET: } 87 \pm 10\end{array}$ \\
\hline
\end{tabular}

$\mathrm{AET}=$ aerobic exercise training; $\mathrm{C}=$ control group; $\mathrm{IMT}=$ inspiratory muscle training; $\mathrm{LVEF}=$ ejection fraction left ventricle; $\mathrm{N} / \mathrm{A}=\mathrm{no}$ available data; $\mathrm{NYHA}=\mathrm{New}$ York Heart Association; $\mathrm{PI}_{\max }=$ maximum inspiratory pressure. * Quasi-experimental study. 
Table 2. Description of the interventions.

\begin{tabular}{|c|c|c|c|c|c|c|}
\hline $\begin{array}{l}\text { Year and } \\
\text { Author }\end{array}$ & Type of IMT & $\begin{array}{l}\text { Intensity of } \\
\text { IMT }\end{array}$ & $\begin{array}{l}\text { Duration per } \\
\text { Session } \\
\text { (min) }\end{array}$ & $\begin{array}{l}\text { Frequency } \\
\text { per Week } \\
\text { (days) }\end{array}$ & $\begin{array}{l}\text { Duration of } \\
\text { Intervention } \\
\text { (weeks) }\end{array}$ & Extra Commentary \\
\hline $\begin{array}{c}2008 . \\
\text { Chiappa } \\
\text { et al. [67] * }\end{array}$ & $\begin{array}{c}\text { Threshold } \\
\text { device }\end{array}$ & $\begin{array}{l}\text { IMT: } 30 \% \\
\text { PI }{ }_{\max }\end{array}$ & IMT: 30 & IMT: 7 & 4 & $\begin{array}{l}\text { Control group without intervention. } \\
\text { In the experimental group, the intensity } \\
\text { was readjusted weekly and one session } \\
\text { weekly was supervised. }\end{array}$ \\
\hline $\begin{array}{c}2008 . \\
\text { Laoutaris } \\
\text { et al. [66] }\end{array}$ & $\begin{array}{c}\text { Resistive load } \\
\text { device }\end{array}$ & $\begin{array}{c}\text { IMT: } 60 \% \\
\text { SMIP } \\
\text { C: } 15 \% \text { SMIP }\end{array}$ & $\begin{array}{l}\text { IMT: N/A } \\
\text { C: N/A }\end{array}$ & $\begin{array}{l}\text { IMT: } 3 \\
\text { C: } 3\end{array}$ & 10 & $\begin{array}{l}\text { All sessions were supervised. In the } \\
\text { experimental group, the intensity was } \\
\text { readjusted in each session; in the control } \\
\text { group, it was fixed. } \\
\text { The session had six efforts at each level: } \\
\text { Level I: } 60 \mathrm{~s} \text { for rest in each } \\
\text { inspiration effort } \\
\text { Level II: } 45 \mathrm{~s} \text { for rest between series } \\
\text { Level III: } 30 \mathrm{~s} \text { for rest between series } \\
\text { Level IV: } 15 \mathrm{~s} \text { for rest between series } \\
\text { Level V: } 10 \mathrm{~s} \text { for rest between series } \\
\text { Level VI: } 5 \mathrm{~s} \text { for rest between series. } \\
\text { After level VI, rest for } 5 \mathrm{~s} \text { maintained up to } \\
\text { respiratory fatigue process. }\end{array}$ \\
\hline $\begin{array}{l}2012 . \\
\text { Mello et al. [74] }\end{array}$ & $\begin{array}{c}\text { Threshold } \\
\text { device }\end{array}$ & $\begin{array}{l}\text { IMT: } 30 \% \\
\text { PI }_{\max }\end{array}$ & $\begin{array}{l}\text { IMT: } 10 \min x \\
\text { 3/day }\end{array}$ & IMT: 7 & 13 & $\begin{array}{l}\text { Control group had usual care. } \\
\text { In the experimental group, the intensity } \\
\text { was readjusted weekly and one session } \\
\text { weekly was supervised. }\end{array}$ \\
\hline $\begin{array}{l}\text { 2017. Moreno } \\
\text { et al. [28] }\end{array}$ & $\begin{array}{l}\text { Threshold or } \\
\text { resistive load } \\
\text { devices }\end{array}$ & $\begin{array}{l}\text { IMT: } 30 \% \\
\text { PI }{ }_{\max }\end{array}$ & IMT: $30 \mathrm{~min}$ & IMT: 6 & 8 & $\begin{array}{l}\text { Control group without intervention. } \\
\text { In the experimental group, the intensity } \\
\text { was readjusted weekly and one session } \\
\text { weekly was supervised. }\end{array}$ \\
\hline $\begin{array}{l}2020 . \\
\text { Antunes } \\
\text { Correa } \\
\text { et al. [85] }\end{array}$ & $\begin{array}{c}\text { Resistive load } \\
\text { device }\end{array}$ & $\begin{array}{l}\text { IMT: } 60 \% \\
\text { PI }\end{array}$ & $\begin{array}{l}\text { IMT: } 30 \mathrm{~min} \\
\text { AET: } 60\end{array}$ & $\begin{array}{l}\text { IMT: } 5 \\
\text { AET: } 3\end{array}$ & 16 & $\begin{array}{l}\text { Control group without intervention. } \\
\text { In the experimental group, the intensity } \\
\text { was readjusted weekly and one session } \\
\text { weekly was supervised. } \\
\text { In the AET group, all sessions were } \\
\text { supervised. Sessions comprised } 5 \text { min for } \\
\text { stretching exercise, } 40 \text { min for cycling, } 10 \\
\text { min for local strengthening exercise and } 5 \\
\text { min for cooldown. Aerobic exercise was } \\
\text { performed under anaerobic thresholds up } \\
\text { to } 10 \% \text { under respiratory } \\
\text { compensation points. }\end{array}$ \\
\hline
\end{tabular}

$\mathrm{AET}=$ aerobic exercise training; $\mathrm{C}=$ control group; $\mathrm{IMT}=$ inspiratory musculature training; $\mathrm{N} / \mathrm{A}=$ no available data; $\mathrm{SMIP}=$ sustained maximum inspiratory pressure. * Quasi-experimental study.

Cardiac rehabilitation may be considered a comprehensive rehabilitation program that improves functional capacities under HF condition. Currently, cardiac programs for rehabilitation seem to be underutilized [87]. IMT intervention is a useful alternative therapy that is suitable for the participation of HF patients. In addition, IMT may be adequate for patients who are not candidates for cardiac programs for rehabilitation, such as individuals unable to carry out exercises, so it is considered a useful personalized medicine intervention $[42,58]$. Inspiratory muscle weakness presented in HF patients may be reversible.

Regarding metaboreflex activity, five studies $[28,66,67,74,85]$ detailed IMT effects on respiratory muscle meta-reflexes; statistically significant improvements $(p<0.05)$ were claimed in four of them, but such improvements were not found in the study performed by Laoutaris et al. [66]. A total of three studies [67,74,85] analyzed IMT effects on blood flow of limb muscles for rest and exercise activity. These studies reported improvements in this parameter due to vascular resistance reduction in limbs, except for Laoutaris et al.'s [66] study, which did not observe any statistically significant difference $(p>0.05)$ in the blood flow of forearms between intervention groups, although the reactive hyperemic blood flow of forearms showed statistically significant improvement $(p<0.05)$ due to IMT in- 
tervention. IMT produces statistically significant increases $(p<0.05)$ in ventilation loads required in order to produce peripheral vasoconstrictions by the respiratory musculature meta-reflexes. Such a fact could be explained by higher fatigue resistances in those muscles, producing a reduction in metabolite accumulation that triggers activation of the metareflexes $[28,67,74,85]$. Therefore, IMT may be linked to an inspiratory muscle release effect by greater inspiratory muscle thickness, diaphragmatic muscular aerobic capacity and strength. These effects were linked to a reduction of the accumulation of metabolites as well as decreased peripheral vasoconstriction, leading to greater peripheral blood flows as well as higher exercise tolerance $[27,46,67]$. Following the reported meta-reflexes reduction, Mello et al. [74] detailed that IMT decreased muscular sympathetic activities, producing an improvement of the vagal and sympathetic modulations for cardiovascular systems under HF condition. In addition, the reduction of the sympathetic adrenal activity may be explained as secondary to the chemo-reflex reduction due to IMT provoking an improvement in oxygen saturation. Indeed, Moreno et al. [28] detailed how respiratory muscle meta-reflexes were reduced by IMT intervention. In conclusion, an improvement in the oxygen saturations for forearm and/or intercostal musculature was reported, improving the muscles' $\mathrm{O}_{2}$ diffusion. Thus, IMT may be a suitable intervention to decrease the inspiratory musculature meta-reflexes under HF condition, which would be a key intervention option for personalized medicine in HF patients.

\subsection{Future Research and Limitations}

Although statistical significance and data extraction were accurately detailed, methodological quality analyses, risks of bias, heterogeneity analysis and forest plots were not included because confidence intervals were not detailed for all studies. Our study's records showed heterogeneity and did not permit us to perform systematic reviews and/or meta-analyses. These issues justified this narrative review to detail the available scientific evidence about IMT effects on respiratory muscle metaboreflex activity of HF patients. Furthermore, the present narrative review included the available experimental records, including clinical trials as quasi-experimental records that analyzed IMT effects on respiratory muscle metaboreflex in HF patients. Future research studies should perform high-quality meta-analyses and systematic reviews following the PRISMA criteria [57] to provide updated strong evidence about IMT effects on respiratory muscle metaboreflex in HF patients [42,58].

It is worth noting that the accuracy of distinguishing between primary or muscular and vascular induced HF or weakness may present some difficulties because the proposed methods seem to be less suitable for this differential diagnosis, as discussed by Guski et al. [88]. These authors proposed the use of specific antibodies to provide information about the immunoreactivity of ischemia-damaged cardiomyocytes. In addition, some future studies should consider virtual autopsy for HF prediction because this method may offer additional benefits for digital tissue-based diagnosis, such as tissue or organ dysfunctions and the HF patient's prognosis [89].

\section{Conclusions}

Currently available scientific evidence seems to affirm that excessive metaboreflex activity of respiratory musculature under HF condition is one of the main causes of exercise intolerance and sympathetic-adrenal system hyperactivity. IMT seems to be a useful personalized medicine intervention to reduce respiratory muscle metaboreflex in order to improve exercise tolerance in $\mathrm{HF}$ patients.

Author Contributions: All authors have equally contributed to the manuscript, including in conceptualization, data curation, investigation, methodology, supervision, writing-original draft, and writing-review and editing. All authors have read and agreed to the published version of the manuscript.

Funding: This research received no external funding. 
Institutional Review Board Statement: Not applicable.

Informed Consent Statement: Not applicable.

Data Availability Statement: Data will be available upon corresponding author request.

Conflicts of Interest: The authors declare no conflict of interest.

\section{References}

1. Chaudhry, S.P.; Stewart, G.C. Advanced Heart Failure: Prevalence, Natural History, and Prognosis. Heart Fail. Clin. 2016, 12, 323-333. [CrossRef]

2. Tanai, E.; Frantz, S. Pathophysiology of Heart Failure. Compr. Physiol. 2015, 6, 187-214. [CrossRef]

3. Poole, D.C.; Copp, S.W.; Hirai, D.M.; Musch, T.I. Dynamics of muscle microcirculatory and blood-myocyte $\mathrm{O}_{2}$ flux during contractions. Acta Physiol. 2010, 202, 293-310. [CrossRef]

4. Dickstein, K.; Cohen-Solal, A.; Filippatos, G.; McMurray, J.J.; Ponikowski, P.; Poole-Wilson, P.A.; Strömberg, A.; Van Veldhuisen, D.J.; Atar, D.; Hoes, A.W.; et al. ESC Guidelines for the diagnosis and treatment of acute and chronic heart failure 2008: The Task Force for the Diagnosis and Treatment of Acute and Chronic Heart Failure 2008 of the European Society of Cardiology. Developed in collaboration with the Heart Failure Association of the ESC (HFA) and endorsed by the European Society of Intensive Care Medicine (ESICM). Eur. Heart J. 2008, 29, 2388-2442. [CrossRef]

5. Piepoli, M.F.; Dimopoulos, K.; Concu, A.; Crisafulli, A. Cardiovascular and ventilatory control during exercise in chron-ic heart failure: Role of muscle reflexes. Int. J. Cardiol. 2008, 130, 3-10. [CrossRef]

6. Warriner, D.; Sheridan, P.; Lawford, P. Heart failure: Not a single organ disease but a multisystem syndrome. Br. J. Hosp. Med. 2015, 76, 330-336. [CrossRef]

7. Laoutaris, I.D. The 'aerobic/resistance/inspiratory muscle training hypothesis in heart failure'. Eur. J. Prev. Cardiol. 2018, 25, 1257-1262. [CrossRef]

8. Lloyd-Jones, D.; Adams, R.J.; Brown, T.M.; Carnethon, M.; Dai, S.; De Simone, G.; Ferguson, T.B.; Ford, E.; Furie, K.; Gillespie, C.; et al. Executive summary: Heart disease and stroke statistics-2010 update: A report from the american heart association. Circulation 2010, 121, 948-954.

9. Fisher, J.D. New York Heart Association Classification. Arch. Intern. Med. 1972, 129, 836. [CrossRef]

10. Lalande, S.; Cross, T.J.; Keller-Ross, M.L.; Morris, N.R.; Johnson, B.D.; Taylor, B.J. Exercise Intolerance in Heart Failure: Central Role for the Pulmonary System. Exerc. Sport Sci. Rev. 2020, 48, 11-19. [CrossRef]

11. Nakagawa, N.K.; Diz, M.A.; Kawauchi, T.S.; De Andrade, G.N.; Umeda, I.I.K.; Murakami, F.M.; Oliveira-Maul, J.P.; Nascimento, J.A.; Nunes, N.; Takada, J.Y.; et al. Risk Factors for Inspiratory Muscle Weakness in Chronic Heart Failure. Respir. Care 2019, 65, 507-516. [CrossRef]

12. Clark, A.L.; Poole-Wilson, P.A.; Coats, A.J. Exercise limitation in chronic heart failure: Central role of the periphery. J. Am. Coll. Cardiol. 1996, 28, 1092-1102. [CrossRef]

13. Nilsson, K., Jr.; Duscha, B.D.; Hranitzky, P.M.; Kraus, W.E.; Nilsson, K.R. Chronic Heart Failure and Exercise Intolerance: The Hemodynamic Paradox. Curr. Cardiol. Rev. 2008, 4, 92-100. [CrossRef]

14. Hammond, M.D.; Bauer, K.A.; Sharp, J.T.; Rocha, R.D. Respiratory Muscle Strength in Congestive Heart Failure. Chest 1990, 98, 1091-1094. [CrossRef]

15. Walsh, J.T.; Andrews, R.; Johnson, P.; Phillips, L.; Cowley, A.J.; Kinnear, W.J. Inspiratory muscle endurance in patients with chronic heart failure. Heart 1996, 76, 332-336. [CrossRef]

16. Sullivan, M.J.; Green, H.J.; Cobb, F.R. Skeletal muscle biochemistry and histology in ambulatory patients with long-term heart failure. Circulation 1990, 81, 518-527. [CrossRef]

17. Mancini, N.M.; Henson, D.; LaManca, J.; Levine, S. Evidence of reduced respiratory muscle endurance in patients with heart failure. J. Am. Coll. Cardiol. 1994, 24, 972-981. [CrossRef]

18. Piepoli, M.; Clark, A.L.; Volterrani, M.; Adamopoulos, S.; Sleight, P.; Coats, A.J. Contribution of Muscle Afferents to the Hemodynamic, Autonomic, and Ventilatory Responses to Exercise in Patients with Chronic Heart Failure. Circulation 1996, 93, 940-952. [CrossRef] [PubMed]

19. Clark, A.L. Origin of symptoms in chronic heart failure. Heart 2006, 92, 12-16. [CrossRef] [PubMed]

20. Boushel, R. Muscle metaboreflex control of the circulation during exercise. Acta Physiol. 2010, 199, 367-383. [CrossRef]

21. Katayama, K.; Saito, M. Muscle sympathetic nerve activity during exercise. J. Physiol. Sci. 2019, 69, 589-598. [CrossRef] [PubMed]

22. Fisher, J.P.; Young, C.N.; Fadel, P.J. Autonomic Adjustments to Exercise in Humans. Compr. Physiol. 2015, 5, 475-512. [CrossRef] [PubMed]

23. Grotle, A.K.; Macefield, V.G.; Farquhar, W.B.; O'Leary, D.S.; Stone, A.J. Recent advances in exercise pressor reflex function in health and disease. Auton. Neurosci. Basic Clin. 2020, 228, 102698. [CrossRef]

24. Vissing, J.; Vissing, S.F.; MacLean, D.A.; Saltin, B.; Quistorff, B.; Haller, R.G. Sympathetic activation in exercise is not dependent on muscle acidosis. Direct evidence from studies in metabolic myopathies. J. Clin. Investig. 1998, 101, 1654-1660. [CrossRef]

25. Smith, J.R.; Didier, K.D.; Hammer, S.M.; Alexander, A.M.; Kurti, S.P.; Copp, S.W.; Barstow, T.J.; Harms, C.A. Effect of cyclooxygenase inhibition on the inspiratory muscle metaboreflex-induced cardiovascular consequences in men. J. Appl. Physiol. 2017, 123, 197-204. [CrossRef] 
26. Amann, M.; Wan, H.-Y.; Thurston, T.S.; Georgescu, V.P.; Weavil, J.C. On the Influence of Group III/IV Muscle Afferent Feedback on Endurance Exercise Performance. Exerc. Sport Sci. Rev. 2020, 48, 209-216. [CrossRef]

27. Romer, L.M.; Polkey, M.I. Exercise-induced respiratory muscle fatigue: Implications for performance. J. Appl. Physiol. 2008, 104, 879-888. [CrossRef]

28. Moreno, A.M.; Toledo-Arruda, A.C.; Lima, J.S.; Duarte, C.S.; Villacorta, H.; Nóbrega, A.C. Inspiratory Muscle Training Improves Intercostal and Forearm Muscle Oxygenation in Patients with Chronic Heart Failure: Evidence of the Origin of the Respiratory Metaboreflex. J. Card. Fail. 2017, 23, 672-679. [CrossRef]

29. Yamada, K.; Kinugasa, Y.; Sota, T.; Miyagi, M.; Sugihara, S.; Kato, M.; Yamamoto, K. Inspiratory Muscle Weakness Is Associated with Exercise Intolerance in Patients with Heart Failure With Preserved Ejection Fraction: A Preliminary Study. J. Card. Fail. 2016, 22, 38-47. [CrossRef]

30. Ribeiro, J.P.; Chiappa, G.R.; Neder, J.A.; Frankenstein, L. Respiratory muscle function and exercise intolerance in heart failure. Curr. Heart Fail. Rep. 2009, 6, 95-101. [CrossRef]

31. Sheel, A.W.; Boushel, R.C.; Dempsey, J.A. Competition for blood flow distribution between respiratory and locomotor muscles: Implications for muscle fatigue. J. Appl. Physiol. 2018, 125, 820-831. [CrossRef]

32. Ribeiro, J.P.; Chiappa, G.R.; Callegaro, C.C. The contribution of inspiratory muscles function to exercise limitation in heart failure: Pathophysiological mechanisms Contribuição da musculatura inspiratória na limitação ao exercício na in-suficiência cardíaca: Mecanismos fisiopatológicos. Rev. Bras. Fisioter. 2012, 16, 261-268. [CrossRef]

33. Taylor, B.J.; Bowen, T.S. Respiratory Muscle Weakness in Patients with Heart Failure: Time to Make It a Standard Clinical Marker and a Need for Novel Therapeutic Interventions? J. Card. Fail. 2018, 24, 217-218. [CrossRef]

34. Dempsey, J.A.; Romer, L.; Rodman, J.; Miller, J.; Smith, C. Consequences of exercise-induced respiratory muscle work. Respir. Physiol. Neurobiol. 2006, 151, 242-250. [CrossRef]

35. Smith, J.R.; Joyner, M.J.; Curry, T.B.; Borlaug, B.A.; Keller-Ross, M.L.; Van Iterson, E.H.; Olson, T.P. Locomotor muscle group III/IV afferents constrain stroke volume and contribute to exercise intolerance in human heart failure. J. Physiol. 2020, 598, 5379-5390. [CrossRef]

36. Scott, A.C.; Francis, D.P.; Davies, L.C.; Ponikowski, P.; Coats, A.J.S.; Piepoli, M.F. Contribution of skeletal muscle 'ergoreceptors' in the human leg to respiratory control in chronic heart failure. J. Physiol. 2000, 529, 863-870. [CrossRef] [PubMed]

37. Keller-Ross, M.L.; Johnson, B.D.; Carter, R.E.; Joyner, M.J.; Eisenach, J.H.; Curry, T.B.; Olson, T.P. Improved Ventilatory Efficiency with Locomotor Muscle Afferent Inhibition is Strongly Associated with Leg Composition in Heart Failure. Int. J. Cardiol. 2016, 202, 159-166. [CrossRef]

38. Keller-Ross, M.L.; Johnson, B.D.; Joyner, M.J.; Olson, T.P. Influence of the metaboreflex on arterial blood pressure in heart failure patients. Am. Heart J. 2014, 167, 521-528. [CrossRef]

39. Dall'Ago, P.; Chiappa, G.R.; Guths, H.; Stein, R.; Ribeiro, J.P. Inspiratory Muscle Training in Patients With Heart Failure and Inspiratory Muscle Weakness. J. Am. Coll. Cardiol. 2006, 47, 757-763. [CrossRef]

40. Padula, C.A.; Yeaw, E.; Mistry, S. A home-based nurse-coached inspiratory muscle training intervention in heart failure. Appl. Nurs. Res. 2009, 22, 18-25. [CrossRef] [PubMed]

41. Meyer, F.J.; Borst, M.M.; Zugck, C.; Kirschke, A.; Schellberg, D.; Kübler, W.; Haass, M. Respiratory Muscle Dysfunction in Congestive Heart Failure. Circulation 2001, 103, 2153-2158. [CrossRef] [PubMed]

42. Montemezzo, D.; Fregonezi, G.A.; Pereira, D.A.; Britto, R.R.; Reid, W.D. Influence of Inspiratory Muscle Weakness on Inspiratory Muscle Training Responses in Chronic Heart Failure Patients: A Systematic Review and Meta-Analysis. Arch. Phys. Med. Rehabil. 2014, 95, 1398-1407. [CrossRef] [PubMed]

43. Plentz, R.D.M.; Sbruzzi, G.; Ribeiro, R.A.; Ferreira, J.B.; Dal Lago, P. Inspiratory muscle training in patients with heart failure: Meta-analysis of randomized trials. Arq. Bras. Cardiol. 2012, 99, 762-771. [CrossRef]

44. Weiner, P.; Magadle, R.; Berar-Yanay, N.; Pelled, B. The effect of specific inspiratory muscle training on the sensation of dyspnea and exercise tolerance in patients with congestive heart failure. Clin. Cardiol. 1999, 22, 727-732. [CrossRef]

45. Hamazaki, N.; Masuda, T.; Kamiya, K.; Matsuzawa, R.; Nozaki, K.; Maekawa, E.; Noda, C.; Yamaoka-Tojo, M.; Ako, J. Respiratory muscle weakness increases dead-space ventilation ratio aggravating ventilation-perfusion mismatch during exercise in patients with chronic heart failure. Respirology 2018, 24, 154-161. [CrossRef]

46. Cahalin, L.P.; Arena, R.; Guazzi, M.; Myers, J.; Cipriano, G.; Chiappa, G.; Lavie, C.J.; Forman, D.E. Inspiratory muscle training in heart disease and heart failure: A review of the literature with a focus on method of training and outcomes. Expert Rev. Cardiovasc. Ther. 2013, 11, 161-177. [CrossRef]

47. McParland, C.; Krishnan, B.; Wang, Y.; Gallagher, C.G. Inspiratory Muscle Weakness and Dyspnea in Chronic Heart Failure. Am. Rev. Respir. Dis. 1992, 146, 467-472. [CrossRef]

48. Tikunov, B.; Levine, S.; Mancini, D. Chronic Congestive Heart Failure Elicits Adaptations of Endurance Exercise in Diaphragmatic Muscle. Circulation 1997, 95, 910-916. [CrossRef]

49. Hart, N.; Kearney, M.T.; Pride, N.B.; Green, M.; Lofaso, F.; Shah, A.M.; Moxham, J.; Polkey, M.I. Inspiratory muscle load and capacity in chronic heart failure. Thorax 2004, 59, 477-482. [CrossRef]

50. Giallauria, F.; Piccioli, L.; Vitale, G.; Sarullo, F.M.; Sarulli, F.M. Exercise training in patients with chronic heart failure: A new challenge for Cardiac Rehabilitation Community. Monaldi Arch. Chest Dis. 2018, 88, 38-44. [CrossRef] 
51. Cahalin, L.P.; Arena, R.A. Breathing Exercises and Inspiratory Muscle Training in Heart Failure. Heart Fail. Clin. 2015, 11, 149-172. [CrossRef]

52. Olson, T.P.; Joyner, M.J.; Dietz, N.M.; Eisenach, J.H.; Curry, T.B.; Johnson, B.D. Effects of respiratory muscle work on blood flow distribution during exercise in heart failure. J. Physiol. 2010, 588, 2487-2501. [CrossRef]

53. Smith, J.R.; Berg, J.D.; Curry, T.B.; Joyner, M.J.; Olson, T.P. Respiratory muscle work influences locomotor convective and diffusive oxygen transport in human heart failure during exercise. Physiol. Rep. 2020, 8, e14484. [CrossRef]

54. Borghi-Silva, A.; Carrascosa, C.; Oliveira, C.C.; Barroco, A.C.; Berton, D.C.; Vilaça, D.; Lira-Filho, E.B.; Ribeiro, D.; Nery, L.E.; Neder, J.A. Effects of respiratory muscle unloading on leg muscle oxygenation and blood volume during high-intensity exercise in chronic heart failure. Am. J. Physiol. Circ. Physiol. 2008, 294, H2465-H2472. [CrossRef]

55. O'Donnell, D.E.; D'Arsigny, C.; Raj, S.R.; Abdollah, H.; Webb, K.A. Ventilatory Assistance Improves Exercise Endurance in Stable Congestive Heart Failure. Am. J. Respir. Crit. Care Med. 1999, 160, 1804-1811. [CrossRef] [PubMed]

56. Fernandez-Rubio, H.; Becerro-De-Bengoa-Vallejo, R.; Rodríguez-Sanz, D.; Calvo-Lobo, C.; Vicente-Campos, D.; Chicharro, J.L. Inspiratory Muscle Training in Patients with Heart Failure. J. Clin. Med. 2020, 9, 1710. [CrossRef] [PubMed]

57. Moher, D.; Liberati, A.; Tetzlaff, J.; Altman, D.G. Preferred reporting items for systematic reviews and meta-analyses: The PRISMA statement. Int. J. Surg. 2010, 8, 336-341. [CrossRef]

58. Smart, N.A.; Giallauria, F.; Dieberg, G. Efficacy of inspiratory muscle training in chronic heart failure patients: A systematic review and meta-analysis. Int. J. Cardiol. 2013, 167, 1502-1507. [CrossRef] [PubMed]

59. Wong, E.; Selig, S.E.; Hare, D.L. Respiratory Muscle Dysfunction and Training in Chronic Heart Failure. Hear. Lung Circ. 2011, 20, 289-294. [CrossRef] [PubMed]

60. Lin, S.-J.; McElfresh, J.; Hall, B.; Bloom, R.; Farrell, K. Inspiratory Muscle Training in Patients with Heart Failure: A Systematic Review. Cardiopulm. Phys. Ther. J. 2012, 23, 29-36. [CrossRef] [PubMed]

61. Chiappa, G.R.; Roseguini, B.T.; Vieira, P.J.; Alves, C.N.; Tavares, A.; Winkelmann, E.R.; Ferlin, E.L.; Stein, R.; Ribeiro, J.P. Inspiratory Muscle Training Improves Blood Flow to Resting and Exercising Limbs in Patients with Chronic Heart Failure. J. Am. Coll. Cardiol. 2008, 51, 1663-1671. [CrossRef]

62. Stein, R.; Chiappa, G.R.; Güths, H.; Dall'Ago, P.; Ribeiro, J.P. Inspiratory Muscle Training Improves Oxygen Uptake Efficiency Slope in Patients with Chronic Heart Failure. J. Cardiopulm. Rehabil. Prev. 2009, 29, 392-395. [CrossRef]

63. Winkelmann, E.R.; Chiappa, G.R.; Lima, C.O.; Viecili, P.R.; Stein, R.; Ribeiro, J.P. Addition of inspiratory muscle training to aerobic training improves cardiorespiratory responses to exercise in patients with heart failure and inspiratory muscle weakness. Am. Heart J. 2009, 158, 768.e1-768.e7. [CrossRef]

64. Bosnak-Guclu, M.; Arikan, H.; Savci, S.; Inal-Ince, D.; Tulumen, E.; Aytemir, K.; Tokgözoglu, L. Effects of inspiratory muscle training in patients with heart failure. Respir. Med. 2011, 105, 1671-1681. [CrossRef]

65. Laoutaris, I.D.; Adamopoulos, S.; Manginas, A.; Panagiotakos, D.B.; Kallistratos, M.S.; Doulaptsis, C.; Kouloubinis, A.; Voudris, V.; Pavlides, G.; Cokkinos, D.V.; et al. Benefits of combined aerobic/resistance/inspiratory training in patients with chronic heart failure. A complete exercise model? A prospective randomised study. Int. J. Cardiol. 2013, 167, 1967-1972. [CrossRef]

66. Adamopoulos, S.; Schmid, J.-P.; Dendale, P.; Poerschke, D.; Hansen, D.; Dritsas, A.; Kouloubinis, A.; Alders, T.; Gkouziouta, A.; Reyckers, I.; et al. Combined aerobic/inspiratory muscle training vs. aerobic training in patients with chronic heart failure. Eur. J. Hear. Fail. 2014, 16, 574-582. [CrossRef] [PubMed]

67. Marco, E.; Ramírez-Sarmiento, A.L.; Coloma, A.; Sartor, M.; Comin-Colet, J.; Vila, J.; Enjuanes, C.; Bruguera, J.; Escalada, F.; Gea, J.; et al. High-intensity vs. sham inspiratory muscle training in patients with chronic heart failure: A prospective randomized trial. Eur. J. Heart Fail. 2013, 15, 892-901. [CrossRef] [PubMed]

68. Mello, P.R.; Guerra, G.M.; Borile, S.; Rondon, M.U.; Alves, M.J.; Negrão, C.E.; Lago, P.D.; Mostarda, C.; Irigoyen, M.C.; ConsolimColombo, F.M. Inspiratory Muscle Training Reduces Sympathetic Nervous Activity and Improves Inspiratory Muscle Weakness and Quality of Life in Patients with Chronic Heart Failure. J. Cardiopulm. Rehabil. Prev. 2012, 32, 255-261. [CrossRef] [PubMed]

69. Palau, P.; Domínguez, E.; Núñez, E.; Schmid, J.-P.; Vergara, P.; Ramón, J.M.; Mascarell, B.; Sanchis, J.; Chorro, F.J.; Núñez, J. Effects of inspiratory muscle training in patients with heart failure with preserved ejection fraction. Eur. J. Prev. Cardiol. 2014, 21, 1465-1473. [CrossRef]

70. Palau, P.; Domínguez, E.; López, L.; Ramón, J.M.; Heredia, R.; González, J.; Santas, E.; Bodi, V.; Miñana, G.; Valero, E.; et al. Inspiratory Muscle Training and Functional Electrical Stimulation for Treatment of Heart Failure with Preserved Ejection Fraction: The TRAINING-HF Trial. Rev. Española Cardiol. (Engl. Ed.) 2019, 72, 288-297. [CrossRef]

71. Palau, P.; Domínguez, E.; Ramón, J.M.; López, L.; Briatore, A.E.; Tormo, J.P.; Ventura, B.; Chorro, F.J.; Núñez, J. Home-based inspiratory muscle training for management of older patients with heart failure with preserved ejection fraction: Does baseline inspiratory muscle pressure matter? Eur. J. Cardiovasc. Nurs. 2019, 18, 621-627. [CrossRef]

72. Taya, M.; Amiya, E.; Hatano, M.; Maki, H.; Hosoya, Y.; Ishida, J.; Bujo, C.; Tsuji, M.; Konishi, Y.; Yokota, K.; et al. Inspiratory muscle training for advanced heart failure with lamin-related muscular dystrophy. J. Cardiol. Cases 2019, 20, 232-234. [CrossRef]

73. Kawauchi, T.S.; Umeda, I.I.K.; Braga, L.M.; Mansur, A.; Rossi-Neto, J.M.; Sousa, A.G.D.M.R.; Hirata, M.H.; Cahalin, L.P.; Nakagawa, N.K. Is there any benefit using low-intensity inspiratory and peripheral muscle training in heart failure? A randomized clinical trial. Clin. Res. Cardiol. 2017, 106, 676-685. [CrossRef]

74. Pour, A.H.H.; Gholami, M.; Saki, M.; Birjandi, M. The effect of inspiratory muscle training on fatigue and dyspnea in patients with heart failure: A randomized, controlled trial. Jpn. J. Nurs. Sci. 2019, 17, e12290. [CrossRef] 
75. Hornikx, M.; Buys, R.; Cornelissen, V.; Deroma, M.; Goetschalckx, K. Effectiveness of high intensity interval training supplemented with peripheral and inspiratory resistance training in chronic heart failure: A pilot study. Acta Cardiol. 2019, 75, 339-347. [CrossRef]

76. Martínez, A.; Lisboa, C.; Jalil, J.; Muñoz, V.; Díaz, O.; Casanegra, P.; Corbalán, R.; Vásquez, A.M.; Leiva, A. Selective training of respiratory muscles in patients with chronic heart failure. Rev. Médica Chile 2001, 129, 133-139.

77. Frota, A.X.; Mendes, F.D.S.N.S.; Vieira, M.C.; Saraiva, R.M.; Veloso, H.H.; Da Silva, P.S.; Da Silva, G.M.S.; De Sousa, A.S.; Mazzoli-Rocha, F.; Costa, H.S.; et al. Acute and subacute hemodynamic responses and perception of effort in subjects with chronic Chagas cardiomyopathy submitted to different protocols of inspiratory muscle training: A cross-over trial. Disabil. Rehabil. 2020, 1-8. [CrossRef]

78. Marchese, L.D.D.; Chermont, S.; Warol, D.; De Oliveira, L.B.; Pereira, S.B.; Quintão, M.; Mesquita, E.T. Estudo Controlado das Alterações Hemodinâmicas Centrais de uma Sessão de Exercício Inspiratório com Diferentes Cargas na Insuficiência Cardíaca. Arq. Bras. Cardiol. 2020, 114, 656-663. [CrossRef] [PubMed]

79. Antunes-Correa, L.M.; Trevizan, P.F.; Bacurau, A.V.; Ferreira-Santos, L.; Gomes, J.L.; Urias, U.; Oliveira, P.A.; Alves, M.J.N.; De Almeida, D.R.; Brum, P.C.; et al. Effects of aerobic and inspiratory training on skeletal muscle microRNA-1 and downstreamassociated pathways in patients with heart failure. J. Cachex Sarcopenia Muscle 2019, 11, 89-102. [CrossRef] [PubMed]

80. Sadek, Z.; Salami, A.; Youness, M.; Awada, C.; Hamade, M.; Joumaa, W.H.; Ramadan, W.; Ahmaidi, S. A randomized controlled trial of high-intensity interval training and inspiratory muscle training for chronic heart failure patients with inspiratory muscle weakness. Chronic Illn. 2020. [CrossRef] [PubMed]

81. Mancini, N.M.; Henson, D.; La Manca, J.; Donchez, L.; Levine, S.; Manca, J.L. Benefit of Selective Respiratory Muscle Training on Exercise Capacity in Patients with Chronic Congestive Heart Failure. Circulation 1995, 91, 320-329. [CrossRef] [PubMed]

82. Cahalin, L.P.; Semigran, M.J.; Dec, G.W. Inspiratory muscle training in patients with chronic heart failure awaiting cardiac transplantation: Results of a pilot clinical trial. Phys. Ther. 1997, 77, 830-838. [CrossRef] [PubMed]

83. Johnson, P.; Cowley, A.; Kinnear, W. A randomized controlled trial of inspiratory muscle training in stable chronic heart failure. Eur. Hear. J. 1998, 19, 1249-1253. [CrossRef] [PubMed]

84. Laoutaris, I.; Dritsas, A.; Brown, M.D.; Manginas, A.; Alivizatos, P.A.; Cokkinos, D.V. Inspiratory muscle training using an incremental endurance test alleviates dyspnea and improves functional status in patients with chronic heart failure. Eur. J. Cardiovasc. Prev. Rehabil. 2004, 11, 489-496. [CrossRef] [PubMed]

85. Laoutaris, I.D.; Dritsas, A.; Brown, M.D.; Manginas, A.; Kallistratos, M.S.; Degiannis, D.; Chaidaroglou, A.; Panagiotakos, D.B.; Alivizatos, P.A.; Cokkinos, D.V. Immune response to inspiratory muscle training in patients with chronic heart failure. Eur. J. Cardiovasc. Prev. Rehabil. 2007, 14, 679-686. [CrossRef]

86. Laoutaris, I.D.; Dritsas, A.; Brown, M.D.; Manginas, A.; Kallistratos, M.S.; Chaidaroglou, A.; Degiannis, D.; Alivizatos, P.A.; Cokkinos, D.V. Effects of Inspiratory Muscle Training on Autonomic Activity, Endothelial Vasodilator Function, and N-Terminal Pro-brain Natriuretic Peptide Levels in Chronic Heart Failure. J. Cardiopulm. Rehabil. Prev. 2008, 28, 99-106. [CrossRef]

87. Freeman, A.M.; Taub, P.R.; Lo, H.; Ornish, D. Intensive Cardiac Rehabilitation: An Underutilized Resource. Curr. Cardiol. Rep. 2019, 21, 19. [CrossRef]

88. Guski, H.; Kogan, E.A.; Shvalev, V.N. Etiology and Pathogenesis of Sudden Cardiac Death. Diagn. Pathol. 2019, 5, $275-2364$. [CrossRef]

89. Kayser, G.; Kayser, K. Virtual Predictive Autopsy: From knowledge and understanding to education, research and com-munication in digital tissue-Based diagnosis. Diagn. Pathol. 2019, 5, 274-2364. [CrossRef] 